\title{
Pseudolaric acid B induces apoptosis in human rhabdomyosarcoma $\mathrm{RD}$ cells
}

\author{
CHUNYU LIU ${ }^{1,2^{*}}$, FEI WANG ${ }^{3 *}$, BIN WANG $^{4 *}$, TING WU $^{5}$, YUE WANG $^{6}$, WENBO HUO $^{7}$, \\ SHUXIA ZHANG ${ }^{7}$, YING SU ${ }^{7}$, JINMING LIU ${ }^{7}$, YUMENG LIU ${ }^{7}$ and JINGHUA YU ${ }^{1}$ \\ ${ }^{1}$ Institute of Virology and AIDS Research, The First Hospital of Jilin University, Jilin University, Changchun, Jilin 130021; \\ ${ }^{2}$ Acupunture Department, The Affiliated Hospital of Changchun University of Chinese Medicine; \\ ${ }^{3}$ Department of Oral and Maxillofacial Surgery, Hospital of Stomatology, Jilin University, Changchun, Jilin 130000; \\ ${ }^{4}$ Department of Infectious Diseases; ${ }^{5}$ Neonatal Intensive Care Unit, The First Hospital of Jilin University, \\ Jilin University, Changchun, Jilin 130021; ${ }^{6}$ Chemistry Department of Traditional Chinese Medicine, \\ Changchun University of Chinese Medicine; ${ }^{7}$ Department of Experimental Pharmacology and Toxicology, \\ School of Pharmaceutical Science, Jilin University, Changchun, Jilin 130000, P.R. China
}

Received March 4, 2020; Accepted July 30, 2020

DOI: $10.3892 / \mathrm{ol} .2020 .12222$

\begin{abstract}
Pseudolaric acid B (PAB) is a diterpene-type acid isolated from the root and trunk bark of Pseudolarix kaempferi Gordon of the Pinaceae family that has been demonstrated to induce apoptosis in various cell lines and autophagy in certain cell lines including murine fibrosarcoma L929, human thyroid squamous cell carcinoma SW579 and human lung fibroblast MRC5 cells. However, in human rhabdomyosarcoma RD cells, which are derived from the most common soft tissue sarcoma in children and represent a high-grade neoplasm of a skeletal myoblast type, it is not clear whether PAB induces apoptosis or autophagy. The identification of the exact mechanism of PAB is important for studying its antitumor effects and its potential application in the treatment of human rhabdomyosarcoma. To confirm the inhibitory ability of PAB on RD cells, the inhibitory ratio of PAB was analyzed, and the results of MTT assay demonstrated that PAB inhibited RD cell proliferation. Meanwhile aggregation of the microtubule fibers was found in PAB-treated RD cells compared with that in control-treated cells, which was consistent with previous studies. In addition, PAB inhibited RD cell migration, induced apoptosis and cell cycle arrest at the $\mathrm{G} 2 / \mathrm{M}$ phase. These results suggested that the mechanism of PAB-mediated growth inhibition in RD was similar to that reported in the human breast cancer cell line
\end{abstract}

Correspondence to: Dr Jinghua Yu, Institute of Virology and AIDS Research, The First Hospital of Jilin University, Jilin University, 519 Dongming Zhu Street, Changchun, Jilin 130021, P.R. China E-mail: yjh-0-2002@163.com

*Contributed equally

Key words: pseudolaric acid B, apoptosis, cell cycle arrest, human rhabdomyosarcoma RD cells
MCF-7 and the neuroglioma cell line A172; however, it was different from that reported in the L929, MRC5 and SW579 cell lines. Additional experiments demonstrated that PAB regulated the activation of caspase- 8 and caspase- 9 to induce apoptosis and caused an upregulation of phosphorylated $\mathrm{H} 2 \mathrm{~A}$ histone family member $\mathrm{X}$ and cyclin $\mathrm{B} 1$ expression in order to induce cell cycle arrest. Therefore, PAB may be considered a potential treatment agent for human rhabdomyosarcoma.

\section{Introduction}

Pseudolaric acid B (PAB) is a diterpene-type acid isolated from the root and trunk bark of Pseudolarix kaempferi Gordon of the Pinaceae family, also termed 'Tu-Jin-Pi' in Traditional Chinese Medicine, which has been used to treat dermatological fungal infections $(1,2)$. PAB exerts potent inhibition of cell proliferation in vitro in various tumor cell lines by inducing cell cycle arrest and apoptosis in human melanoma cell line A375-S2 and human breast cancer cell line MCF-7 (1-5) or autophagy in murine fibrosarcoma cell line L929 and human thyroid squamous cell line SW579 (6-8). Rhabdomyosarcoma is the most common type of soft tissue sarcoma in children worldwide and represents a high-grade neoplasm of skeletal myoblasts, this tumor accounts for 5-10\% of all childhood tumors since 2002 (9). Surgery and chemotherapy are currently the main treatment methods for rhabdomyosarcoma. In the present study the antitumor effect of PAB on rhabdomyosarcoma was investigated.

Previous studies have focused on apoptosis as a process that can be used for antitumor drug development $(10,11)$. In addition to apoptosis, autophagy is extensively studied in the field of oncology $(12,13)$. Apoptosis, or programmed cell death, refers to a series of biochemical changes in the cell that lead to distinct morphological changes (14). The major mechanisms of apoptosis include the extrinsic pathway, which activates caspase- 8 and caspase-10 in response to external stimuli, and the intrinsic pathway, also termed the mitochondrial pathway, which induces the cleavage of pro-caspase- 9 in response to internal 
stimuli (14). Autophagy is a process during which the components of the cell are delivered to lysosomes for degradation (15). Under certain circumstances, this process may promote cell death and morbidity; however, under the majority of circumstances, autophagy promotes survival by adjusting the cellular response to stress conditions $(16,17)$. Following the induction of apoptosis or autophagy, cell cycle arrest is observed $(6-8,18,19)$. Cell cycle arrest is a tumor-suppressive mechanism, as the cells do not enter the next phase of the retarded phase $(4,7,12)$ and thus, cell proliferation is inhibited.

The present study aimed to prove that PAB inhibited human rhabdomyosarcoma proliferation and to confirm the inhibitory mechanism of $\mathrm{PAB}$, which provided potential opportunities to further develop new drugs for improved clinical outcomes.

\section{Materials and methods}

Materials. PAB was purchased from the National Institute for the Control of Pharmaceutical and Biological Products and was dissolved in dimethyl sulfoxide (DMSO) to produce a stock solution. The DMSO concentration was maintained $<0.01 \%$ in the cell culture and did not exert any detectable effect on cell proliferation or death. Propidium iodide (PI), Hoechst 33258, RNase A, 3-methyladenine (3-MA), 3-(4,5-dimethylthiazol-2-yl)-2,5-diphenyltetrazolium bromide (MTT), monodansylcadaverine (MDC), NBT and BCIP were purchased from Sigma-Aldrich; Merck KGaA. Antibodies against Caspase-8 (cat. no. 66093-1-Ig), caspase-9 (cat. no. 66169-1-Ig), cyclin B1 (cat. no. 55004-1-AP), Beclin 1 (cat. no. 11306-1-AP), LC3 (cat. no. 14600-1-AP), beta actin (cat. no. 66009-1-Ig) and tubulin (cat. no. 10068-1-AP) were purchased from ProteinTech Group, Inc., whereas the antibody against phosphorylated H2A histone family member X ( $\gamma$-H2AX; cat. no. 9718S) was purchased from Cell Signaling Technology, Inc. Alkaline Phosphatase AffiniPure Goat Anti-Mouse IgG (H+L) (cat. no. 115-055-003) and Alkaline Phosphatase AffiniPure Goat Anti-Rabbit IgG (H+L) (cat. no. 111-055-003) were obtained from Jackson ImmunoResearch Laboratories, Inc. HRP-conjugated AffiniPure Goat Anti-Mouse IgG (H+L) (cat. no. SA00001-1), HRP-conjugated AffiniPure Goat Anti-Rabbit IgG $(\mathrm{H}+\mathrm{L})$ (cat. no. SA00001-2), Fluorescein (FITC)-conjugated Affinipure Goat Anti-Rabbit IgG (H+L) (cat. no. SA00003-2) and ECL kit (cat. no. B500014) were purchased from ProteinTech Group, Inc.

Cell culture. Human rhabdomyosarcoma RD cells (cat. no. CCL-136) were obtained from the American Type Culture Collection and cultured in DMEM (HyClone; Cytiva) supplemented with $10 \%$ fetal calf serum (Gibco; Thermo Fisher Scientific, Inc.). The cells were maintained at $37^{\circ} \mathrm{C}$ without $\mathrm{CO}_{2}$ in a humidified atmosphere.

Cell proliferation inhibition test. The inhibition of cell proliferation was determined by MTT assay. RD cells ( $1 \times 10^{4}$ cells/well) were seeded into 96-well culture plates (Nalge Nunc International; Thermo Fisher Scientific, Inc.). Following 24-h culture, $0,2,4,6,8,10,12,14,16,18$ and $20 \mu \mathrm{M}$ of PAB were added to the plates. Following incubation at $37^{\circ} \mathrm{C}$ for 12 , 24,36 or $48 \mathrm{~h}$, respectively, cell proliferation was measured at different time points by adding $20 \mu \mathrm{l}$ MTT $(5 \mathrm{mg} / \mathrm{ml})$ for $3 \mathrm{~h}$ at $37^{\circ} \mathrm{C}$. DMSO $(150 \mu \mathrm{l})$ was added to dissolve the formazan crystals. The absorbance was measured at $492 \mathrm{~nm}$ with an ELISA plate reader (Bio-Rad Laboratories, Inc.). The percentage of inhibition was calculated as follows: Inhibitory ratio $(\%)=$

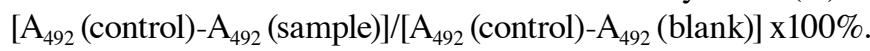

Immunofluorescence assay. RD cells ( $5 \times 10^{5}$ cells/well) were cultured on the cover slips in a 6-well plate. Following 24-h culture, the cells were treated with $4 \mu \mathrm{M}$ PAB for $24 \mathrm{~h}$ at $37^{\circ} \mathrm{C}$, and control cells were treated with equal amount of solvent (DMSO) in 10\% DMEM, then washed with PBS and fixed in $3.7 \%$ formaldehyde at room temperature for $15 \mathrm{~min}$. The cells were subsequently rinsed three times in PBS. The specimens were incubated in blocking buffer (1X PBS; 5\% normal cell culture fetal calf serum; $0.3 \%$ Triton X-100) for $60 \mathrm{~min}$ at room temperature and subsequently with the 1:300 diluted primary antibody against $\beta$-tubulin overnight at $4^{\circ} \mathrm{C}$. The cells were rinsed three times with PBS and incubated with a 1:100 diluted FITC-conjugated secondary antibody for $2 \mathrm{~h}$ at room temperature in the dark. The secondary antibody was aspirated, rinsed once with PBS and stained with Hoechst $33258(5 \mathrm{mg} / \mathrm{l})$ for $30 \mathrm{~min}$ at room temperature. The FITC staining in three fields was visualized by fluorescence microscopy (Leica Microsystems, Inc.; magnification, x400) with an excitation wavelength of $505 \mathrm{~nm}$ and an emission wavelength of $534 \mathrm{~nm}$. Nuclear changes were observed by fluorescence microscopy with an excitation wavelength of $350 \mathrm{~nm}$ and an emission wavelength of $460 \mathrm{~nm}$.

Cell migration. RD cells $\left(5 \times 10^{5}\right.$ cells/well) in 6 -well plates were cultured for $24 \mathrm{~h}$, and a scratch was made randomly with $10-\mu 1$ pipette tips near the center of the well, the lines with same width were chosen, and the cells were treated $4 \mu \mathrm{M}$ PAB or equal DMSO control in DMEM culture medium with $10 \%$ fetal calf serum (7). Along the chosen line, the photograph of the wound was recorded at $0,12,24$ and $36 \mathrm{~h}$ with PAB treatment by phase contrast microscopy (Leica Microsystems, Inc.; magnification, x200), respectively, and the width of wound was labeled with two parallel lines. The test was repeated three times.

Observation of morphological changes by light microscopy. RD cells $\left(5 \times 10^{5}\right.$ cells/well) were cultured in 6 wells plates for $24 \mathrm{~h}$. Subsequently, $4 \mu \mathrm{M}$ PAB was added to the cells for 24 and $48 \mathrm{~h}$, and the morphological changes in three fields were observed by phase contrast microscopy (Leica Microsystems, Inc.; magnification, x200).

Determination of DNA fragmentation by agarose gel electrophoresis. RD cells $\left(5 \times 10^{5}\right.$ cells/well) were cultured in 6 wells plates for $24 \mathrm{~h}$. Subsequently, $4 \mu \mathrm{M}$ PAB was added to the cells for $0,12,24$ or $48 \mathrm{~h}$, respectively. Adherent and floating cells were collected by centrifugation at $1,000 \mathrm{x} \mathrm{g}$ for $5 \mathrm{~min}$ at $4^{\circ} \mathrm{C}$. The cell pellet was suspended in cell lysis buffer (10 mM Tris-HCl, pH 7.4; 10 mM EDTA, pH 8.0; 0.5\% Triton-100) and maintained at $4^{\circ} \mathrm{C}$ for $30 \mathrm{~min}$. The lysate was centrifuged at $25,000 \mathrm{x} \mathrm{g}$ for $20 \mathrm{~min}$ at $4^{\circ} \mathrm{C}$. The supernatant was incubated with $20 \mathrm{~g} / \mathrm{l}$ RNase A $(2 \mu \mathrm{l})$ at $37^{\circ} \mathrm{C}$ for $1 \mathrm{~h}$ and with $20 \mathrm{~g} / \mathrm{l}$ proteinase $\mathrm{K}(2 \mu \mathrm{l})$ at $37^{\circ} \mathrm{C}$ for $1 \mathrm{~h}$, and subsequently 
mixed with $5 \mathrm{M} \mathrm{NaCl}(20 \mu \mathrm{l})$ and isopropanol (120 $\mu \mathrm{l})$ and incubated at $-20^{\circ} \mathrm{C}$ overnight. The samples were centrifuged at $25,000 \mathrm{x} \mathrm{g}$ for $15 \mathrm{~min}$ at $4^{\circ} \mathrm{C}$. The supernatant was discarded, and the DNA sediment was dissolved in TE buffer $(10 \mathrm{mM}$ Tris-HCl, $\mathrm{pH} 7.4 ; 1 \mathrm{mM}$ EDTA, $\mathrm{pH}$ 8.0) and separated by $2 \%$ agarose gel electrophoresis at $100 \mathrm{~V}$ for $50 \mathrm{~min}$.

Flow cytometric analysis of the cell cycle. RD cells $\left(5 \times 10^{5}\right.$ cells/well) were cultured in 6 wells plates for $24 \mathrm{~h}$. Subsequently, $4 \mu \mathrm{M}$ PAB or control medium was added to the cells for $0,12,24$ or $48 \mathrm{~h}$, respectively. Then RD cells were harvested and rinsed with PBS. The cell pellets were fixed in $70 \%$ ethanol at $4^{\circ} \mathrm{C}$ overnight. Following washing twice with PBS, the cells were stained with $1.0-\mathrm{ml}$ solution containing $50 \mathrm{mg} / \mathrm{l} \mathrm{PI}, 1 \mathrm{~g} / \mathrm{l}$ RNase A and $0.1 \%$ Triton X-100 in $3.8 \mathrm{mM}$ sodium citrate on ice in the dark for $30 \mathrm{~min}$. The cell cycle distribution was analyzed by BD CellQuest Pro software version 5.1 (BD Biosciences) in BD FACSCalibur flow cytometer (Becton Dickinson and Company). The histograms were analyzed using ModFit LT version 3.0 software (Verity Software House Inc.) to determine the percentage of cells in each phase of the cell cycle.

MDC staining. The fluorescent compound MDC has been proposed as a tracer for autophagic vacuoles (6-8). RD cells $\left(2 \times 10^{5}\right.$ cells/well $)$ were cultured in 6 wells plates for $24 \mathrm{~h} .24 \mathrm{~h}$ later, RD cells were treated with $4 \mu \mathrm{M}$ PAB for another $24 \mathrm{~h}$ and incubated with $0.05 \mathrm{mM} \mathrm{MDC}$ at $37^{\circ} \mathrm{C}$ for $1 \mathrm{~h}$. Following incubation, the cells were washed once with PBS. Intracellular MDC in three fields was measured by fluorescence microscopy at an excitation wavelength of $380 \mathrm{~nm}$ and an emission wavelength of $525 \mathrm{~nm}$ (Leica Microsystems, Inc.; magnification, $\mathrm{x} 200$ ).

3-MA treatment. The RD cells were treated with PAB $(4 \mu \mathrm{M})$ together/or 3-MA (2 mM) for $24 \mathrm{~h}$.

Western blot analysis of total cytoplasmic and nuclear protein expression. RD cells $\left(1 \times 10^{6}\right.$ cells/well $)$ were cultured in a $25-\mathrm{ml}$ culture bottle for $24 \mathrm{~h}$ and subsequently treated with $4 \mu \mathrm{M} \mathrm{PAB}$ for $24 \mathrm{~h}$. Adherent and floating cells were collected and frozen at $-80^{\circ} \mathrm{C}$. Western blot analysis was performed for the determination of the total protein expression as previously described (4). Briefly, protein ( $40 \mu \mathrm{g} /$ lane) was loaded in $10 \%$ SDS-PAGE and transferred onto nitrocellulose membrane. The membranes were blocked for $1 \mathrm{~h}$ at room temperature in blocking buffer [5\% nonfat dry milk in $1 \mathrm{X}$ TBST (Tris-HCL $1.576 \mathrm{~g} / \mathrm{l}, \mathrm{NaCl}$ $8.00 \mathrm{~g} / 1$, Tween-20 0.1\%)]. Then the membranes were incubated with primary polyclonal antibody $(1: 1,000)$ including caspase-8 (cat. no. 66093-1-Ig; ProteinTech Group, Inc.), caspase-9 (cat. no. 66169-1-Ig; ProteinTech Group, Inc.), cyclin B1 (cat. no. 55004-1-AP; ProteinTech Group, Inc.), Beclin 1 (cat. no. 11306-1-AP; ProteinTech Group Inc.), LC3 (cat. no. 14600-1-AP; ProteinTech Group, Inc.), $\beta$-actin (cat. no. 66009-1-Ig; ProteinTech Group, Inc.) and tubulin (cat. no. 10068-1-AP; ProteinTech Group, Inc.), or phosphorylated H2A histone family member X ( $\gamma-\mathrm{H} 2 \mathrm{AX}$; cat. no. $9718 \mathrm{~S}$; Cell Signaling Technology, Inc.) at $4^{\circ} \mathrm{C}$ overnight, washed three times for 5 min each with TBST and incubated with the appropriate secondary polyclonal antibody $(1: 2,000)$

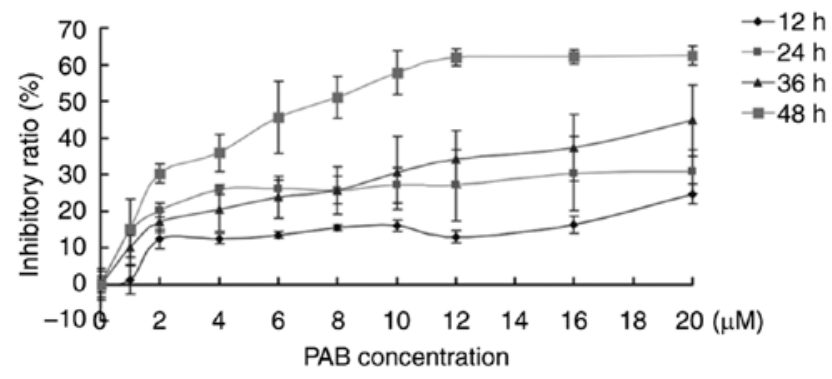

Figure 1. Inhibitory effect of $\mathrm{PAB}$ on RD cell proliferation. RD cells were incubated with different doses of PAB for 12, 24, 36 and $48 \mathrm{~h}$, and the proliferation inhibition was evaluated by the MTT assay. Data are presented as the mean $\pm \mathrm{SD} ; \mathrm{n}=3$. PAB, pseudolaric acid $\mathrm{B}$.

including Alkaline Phosphatase AffiniPure Goat Anti-Mouse IgG (H+L) (cat. no. 115-055-003; Jackson ImmunoResearch Laboratories, Inc.), Alkaline Phosphatase AffiniPure Goat Anti-Rabbit IgG (H+L) (cat. no. 111-055-003; Jackson ImmunoResearch Laboratories, Inc.), HRP-conjugated AffiniPure Goat Anti-Mouse IgG (H+L) (cat. no. SA00001-1; ProteinTechGroup, Inc.) or HRP-conjugated AffiniPure Goat Anti-Rabbit IgG (H+L) (cat. no. SA00001-2; ProteinTech Group, Inc.) at room temperature for $1 \mathrm{~h}$. The loading control used was tubulin or actin. The proteins were visualized using NBT and BCIP for the AP-conjugated secondary antibody for Fig. 5 and the data was collected by Canon Scan (9000F MarkII; Canon); and using the ECL kit for the HRP-conjugated secondary antibody for Fig. 6 and the data was collected by Azure C500 (Azure Biosystems).

Statistical analysis. All experiments were performed independently $\geq 3$ times, and the data are presented as the mean \pm SD. Statistical analysis was performed using SPSS 10.0 software (SPSS, Inc.). Differences between two groups at various timepoints were assessed using one-way repeated measures ANOVA. Differences among multiple groups were assessed using one-way ANOVA with Tukey's post hoc test. $\mathrm{P}<0.05$ was considered to indicate a statistically significant difference.

\section{Results}

$P A B$ inhibits $R D$ cell proliferation. In the present study, the inhibitory role of PAB was investigated in human rhabdomyosarcoma RD cells. The results of the MTT assay demonstrated that 1-20 $\mu \mathrm{M}$ PAB inhibited cell proliferation, and between 12 and $48 \mathrm{~h}$, the inhibitory ability of PAB increased (Fig. 1). At $36 \mathrm{~h}$, the $\mathrm{IC}_{50}$ was estimated to be $41 \mu \mathrm{M}$, and at $48 \mathrm{~h}$, the $\mathrm{IC}_{50}$ was $7.5 \mu \mathrm{M}$. At $48 \mathrm{~h}, 4 \mu \mathrm{M}$ of PAB inhibited RD cell proliferation with an inhibitory ratio of $35 \%$ (Fig. 1). These results were consistent with previous studies $(4,5)$; therefore, $4 \mu \mathrm{M}$ PAB was selected for subsequent experiments.

$P A B$ alters tubulin distribution. $\mathrm{PAB}$ has been reported to target tubulin $(20,21)$. Therefore, the current study investigated the effects of PAB on the microtubule networks of RD cells by tubulin immunofluorescence staining. Treatment of RD cells with $4 \mu \mathrm{M}$ PAB for $24 \mathrm{~h}$ resulted in the aggregation of the microtubule fibers compared with that observed in cells that had undergone a control treatment (Fig. 2). To verify the 

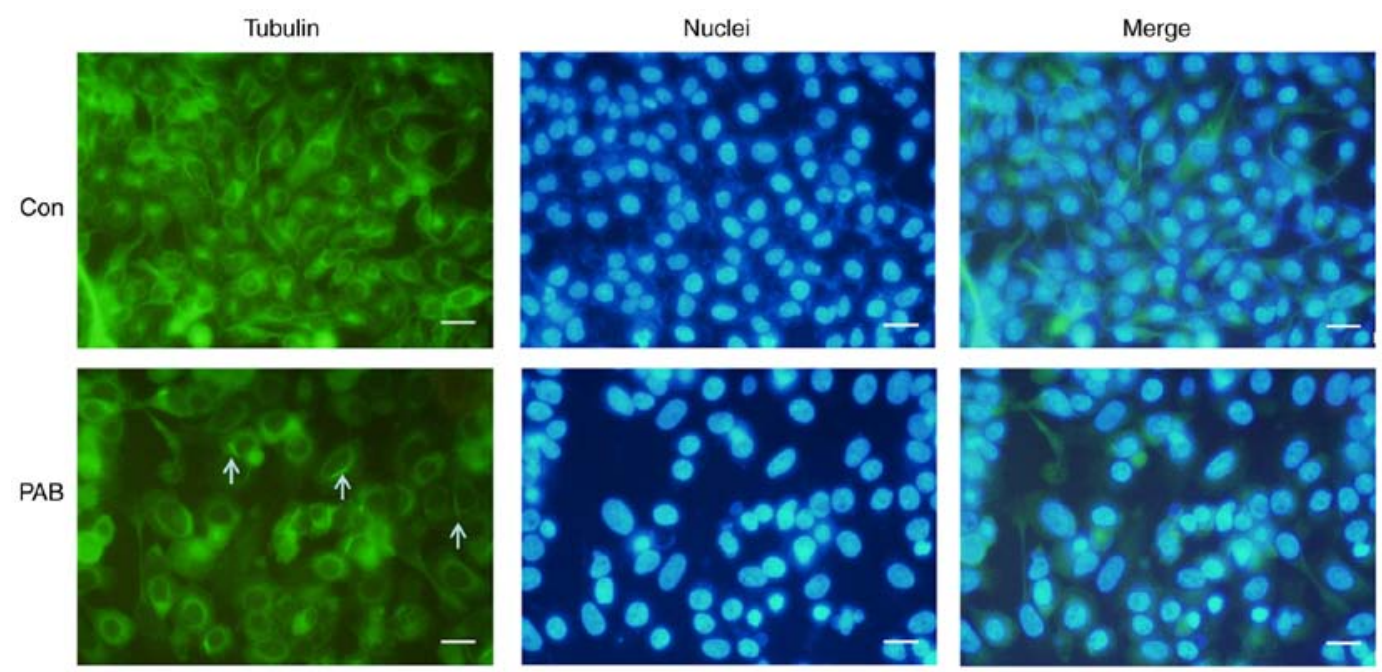

Figure 2. PAB affects tubulin aggregation in RD cells. Tubulin (green) is stained with FITC labeled-secondary antibody and Hoechst 33258 (blue) was used to stain the nuclei. Arrows indicate the aggregation of tubulin. Scale bar, $15 \mu \mathrm{m}$. PAB, pseudolaric acid B; Con, control.

$0 \mathrm{~h}$
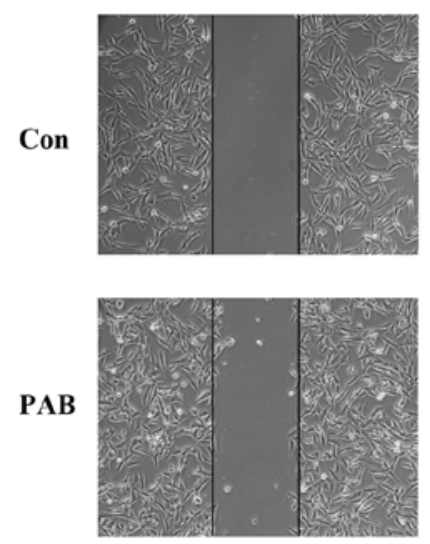

$12 \mathrm{~h}$
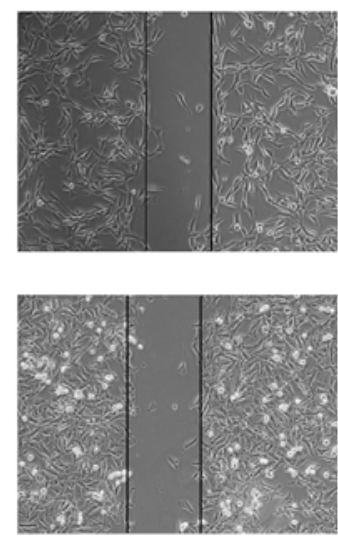

$24 \mathrm{~h}$
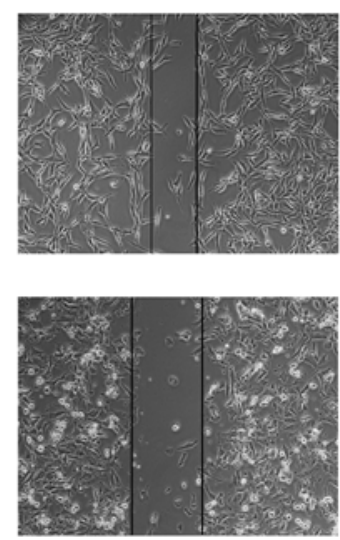

$36 \mathrm{~h}$
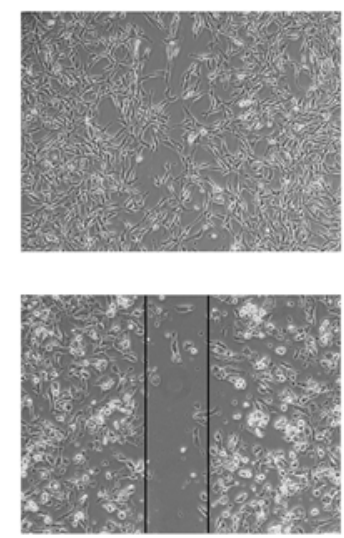

Figure 3. PAB inhibits cell migration. At $0,12,24$ and $36 \mathrm{~h}$ after $4 \mu \mathrm{M}$ PAB treatment, the width was recorded. The data are representative of three individual experiments $(\mathrm{n}=3)$. PAB, pseudolaric acid $\mathrm{B}$; Con, control.

location of the aggregation of the microtubule fibers, the cell nuclei were stained, and the results demonstrated that the fibers were located in the cytoplasm (Fig. 2). At the same time, it was noted that cells became larger and nuclei became larger in PAB-treated group, which was consistent with a previous study (22), so it was speculated that PAB resulted in the aggregation of the microtubule fibers, and cells could not divide although DNA replication had been completed.

$P A B$ inhibits cell migration. The effects of PAB on RD cell migration were assessed by wound healing assay. The results demonstrated that RD cells migrated over time (from 0 to $36 \mathrm{~h}$ ), since the edge of the wound gradually disappeared, which was consistent with the effects noted in the aggregation of microtubule fibers. However, following PAB treatment, the edge of the wound was visible by morphological observation at 12, 24 and $36 \mathrm{~h}$ post-treatment (Fig. 3). Therefore, these results indicated that PAB inhibited RD cell migration.

PAB induces apoptosis. To further determine whether PAB induced apoptosis in RD cells, cell morphology was assessed.
At 24 and $48 \mathrm{~h}$, the induction of apoptosis was evident in PAB-treated cells compared with that in the cells that had undergone control treatment; apoptotic bodies and condensed cells were observed in the PAB-treated cells (Fig. 4A). In addition, in the agarose gel electrophoresis assay, no DNA ladder was present at $0 \mathrm{~h}$, whereas the appearance of the DNA ladder was noted at 24, 36 and $48 \mathrm{~h}$ following PAB treatment (Fig. 4B). Following $24 \mathrm{~h}$ post-PAB treatment, the expression levels of pro-caspase- 9 appeared to be decreased, whereas those of active caspase 8 appeared to be increased compared with the control group (Fig. 4C). Although PAB changed the tubulin aggregation, $\mathrm{PAB}$ did not affect tubulin expression, and the expression of tubulin was same as actin and histone (data not shown). These results suggested that PAB induced apoptosis in RD cells.

$P A B$ induces $G 2 / M$ cell cycle arrest. To investigate the mechanism of cell proliferation inhibition mediated by PAB, flow cytometry was used for cell cycle analysis. Following $4 \mu \mathrm{M}$ PAB treatment for $12,24,36$ or $48 \mathrm{~h}$, the cell number of tetraploid cells was increased compared with that in the control 
A
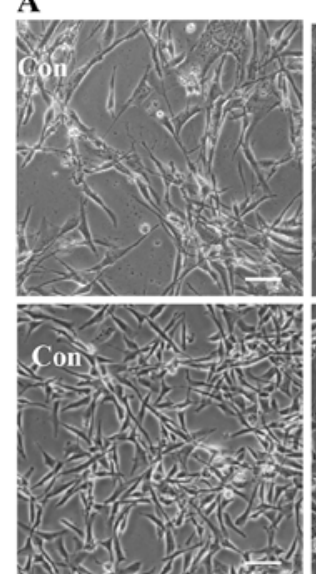
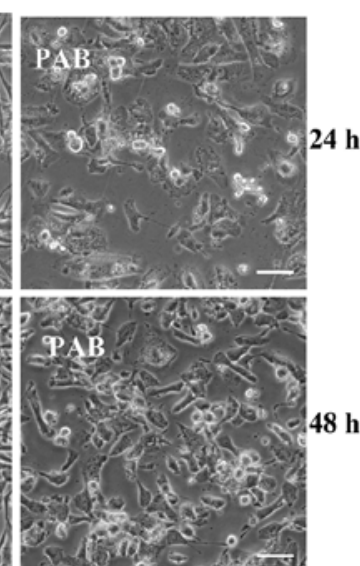

B

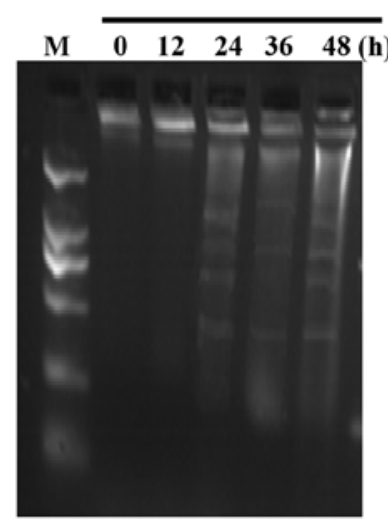

C

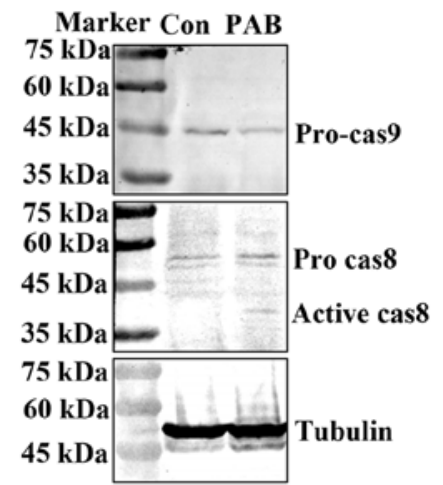

Figure 4. PAB induces apoptosis. (A) Cell morphology was visualized following 24- or 48-h PAB treatment. n=3. Scale bar, $30 \mu \mathrm{m}$. (B) The fragmentation of chromosomal DNA was noted in PAB-treated cells. At $0,12,24,36$ and $48 \mathrm{~h}$, DNA was extracted from RB cells treated with PAB, and the induction of apoptosis was determined by agarose gel electrophoresis. (C) The expression levels of pro-caspase- 9 and active caspase- 8 were determined by western blotting at $24 \mathrm{~h}$ after $4 \mu \mathrm{M} \mathrm{PAB}$ treatment. Representative images of pro-caspase-9, active caspase- 8 and tubulin were from the same batch of samples, but different gels due to the molecular weights of the proteins. Tubulin was used as the loading control. $\mathrm{n}=3$. PAB, pseudolaric acid B; Con, control; M, marker.

A

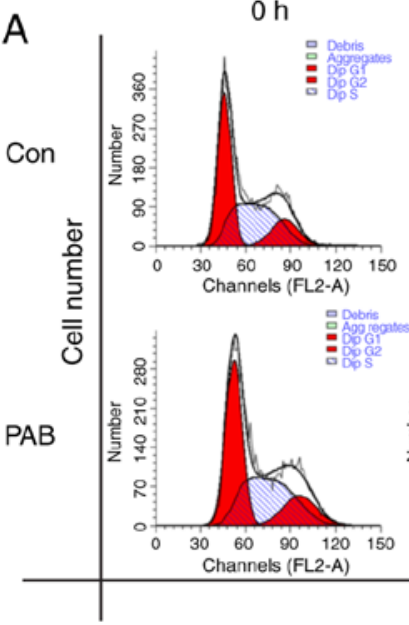

B

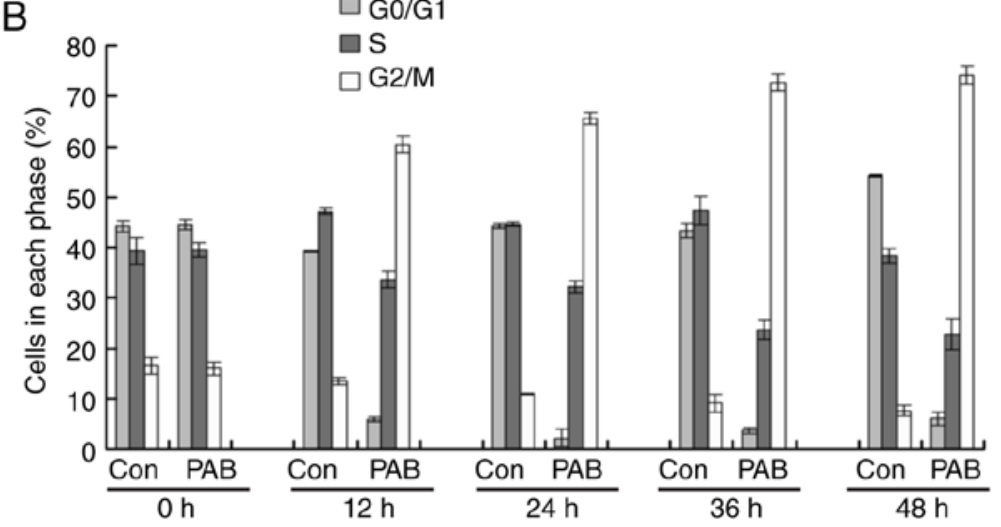

$12 \mathrm{~h}$
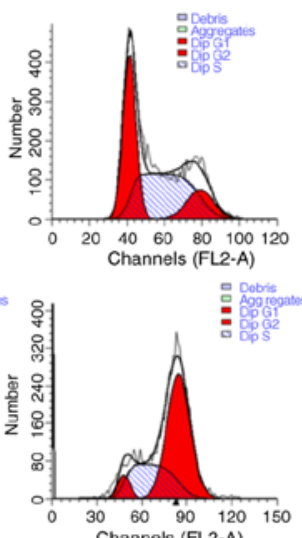
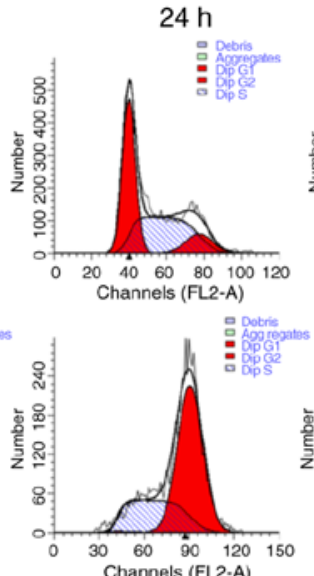
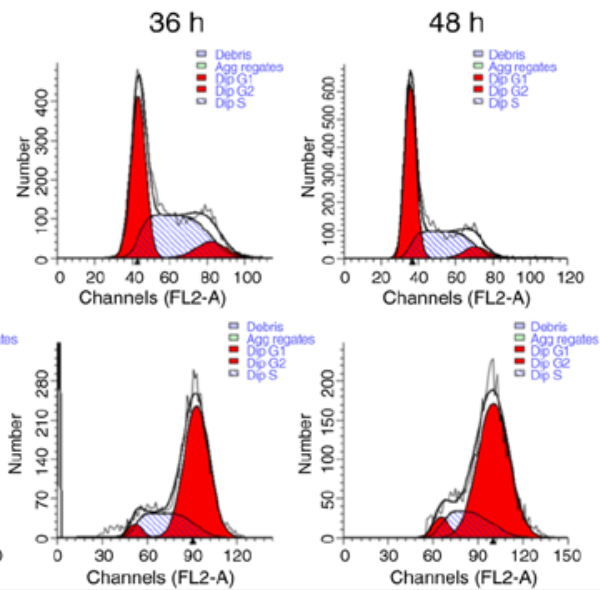

C Marker Con Con PAB

$15 \mathrm{kDa}$

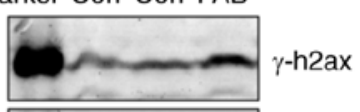

$60 \mathrm{kDa}$

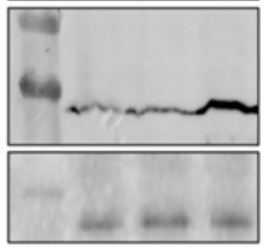

Cyclin B1

$60 \mathrm{kDa}$ Tubulin

Figure 5. PAB induces $\mathrm{G} 2 / \mathrm{M}$ cell cycle arrest. (A) The cell cycle profiles were determined by flow cytometry at the indicated times with $4 \mu \mathrm{M}$ PAB. (B) $4 \mu \mathrm{M}$ PAB induced cell cycle arrest between 0 and $48 \mathrm{~h}$. Data are presented as the mean $\pm \mathrm{SD} ; \mathrm{n}=3$. (C) The expression levels of $\gamma$-H2AX and cyclin B1 in RD cells following treatment with $4 \mu \mathrm{M}$ PAB at $24 \mathrm{~h}$. Images of $\gamma$-H2AX, cyclin $\mathrm{B} 1$ and tubulin blots were from the same batch of samples, but different gels due to the molecular weights of the proteins. The first lane of two control groups is the $0 \mathrm{~h}$ control following PAB treatment, the second lane is the $24 \mathrm{~h}$ control following PAB treatment. $\mathrm{n}=3$. PAB, pseudolaric acid $\mathrm{B} ; \gamma$-H2AX, phosphorylated $\mathrm{H} 2 \mathrm{~A}$ histone family member $\mathrm{X}$.

group (Fig. 5A and B), indicating that the PAB-treated cells were arrested at the $\mathrm{G}_{2} / \mathrm{M}$ phase. Western blot analysis results demonstrated that PAB treatment upregulated the expression levels of $\gamma$-H2AX and cyclin B1 at $24 \mathrm{~h}$ post-treatment (Fig. 5C). Therefore, PAB induced cell cycle arrest, which was likely in the $M$ phase. 
A
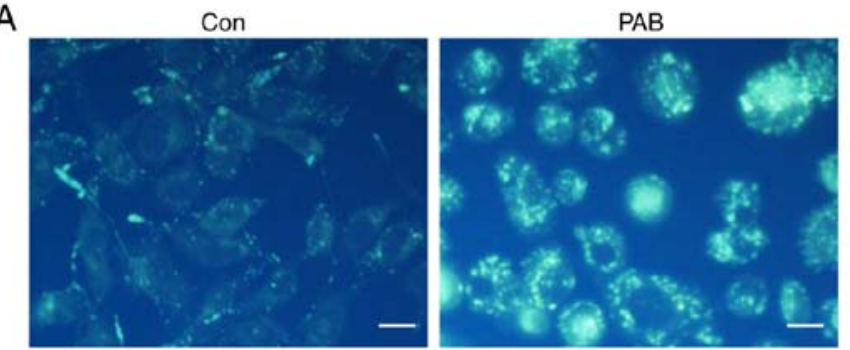

B

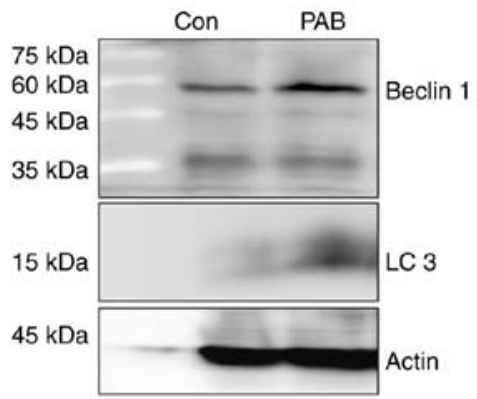

C

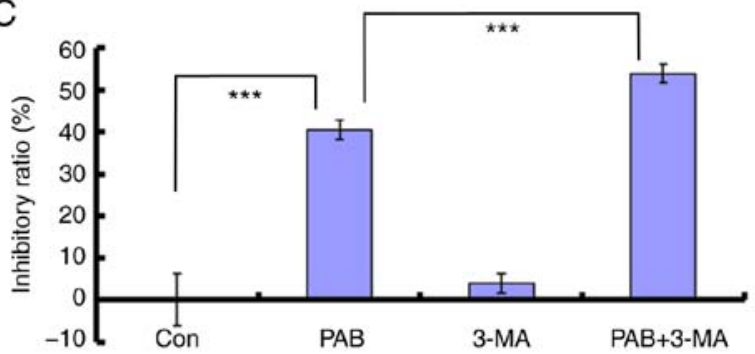

D

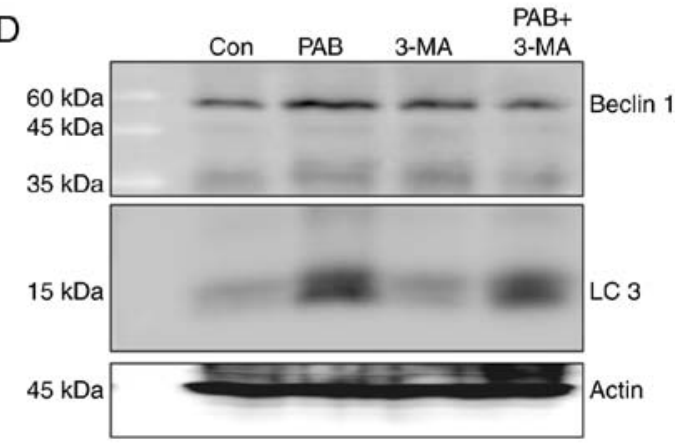

Figure 6. PAB induces autophagy and inhibits autophagy-mediated cell death. (A) At $24 \mathrm{~h}, 4 \mu \mathrm{M}$ PAB increased the positive dots of MDC staining as determined by fluorescence microscopy. Scale bar, $15 \mu \mathrm{m}$. (B) The expression levels of Beclin 1 and LC3 following PAB treatment. Representative images of beclin 1, actin and LC3 blots were from different gels, but the same batch of samples. (C) Proliferation inhibition was evaluated by the MTT assay at $24 \mathrm{~h}$ following PAB treatment. 3-MA is an autophagy inhibitor. Data are presented as the mean $\pm \mathrm{SD}, \mathrm{n}=3$. ${ }^{* * *} \mathrm{P}<0.001$. (D) The expression levels of beclin 1 and LC3 following PAB or 3-MA treatment at $24 \mathrm{~h}$ post-PAB treatment. Representative images of beclin 1 , LC3 and actin blots are from different gels, but the same batch of samples. PAB, pseudolaric acid B; MDC, monodansylcadaverine.

$P A B$ induces autophagy. To further confirm the role of PAB in inhibiting cell proliferation, the current study examined whether PAB induced autophagy in RB cells. The results demonstrated that $4 \mu \mathrm{M}$ PAB increased the MDC-positive points, which are considered to be markers of autophagy $(6,7)$ (Fig. 6A). The present study further demonstrated that at $24 \mathrm{~h}$, the expression levels of autophagy markers beclin 1 and LC3 were increased in $\mathrm{RB}$ cells treated with PAB compared with those in the control group (Fig. 6B). In the presence of the autophagy inhibitor 3-MA (2 mM), an increased proliferation inhibition ratio was observed in PAB-treated cells compared with control treatment (Fig. 6C), and comparing to PAB treatment group, the expression level of beclin 1 was decreased in PAB together with 3-MA treatment group, and LC3 had a decreased trend (Fig. 6D). Therefore, inhibiting autophagy promotes cell death in PAB-treated RD cells.

\section{Discussion}

PAB exhibits potent antitumor effects on human breast cancer MCF-7, cervical cancer HeLa and melanoma A375 cells by inducing apoptosis (1-5), and on murine fibrosarcoma L929, human thyroid squamous cell carcinoma SW579 cells and human lung fibroblasts MRC5 by inducing autophagy (6-8). In the present study, the effects of PAB were examined on human rhabdomyosarcoma RD cell proliferation. The present study provided novel information that may aid further translation of new candidate drugs into improved clinical treatments.

The results of the present study demonstrated that $\mathrm{PAB}$ inhibited RD cell proliferation. PAB inhibits the proliferation of several types of cancer cells, and the present study broadens the antineoplastic spectrum of PAB through confirming PAB inhibiting Rhabdomyosarcoma RD cell growth and cell migration and inducing apoptosis and cell cycle arrest.

Previous studies have demonstrated that PAB induces apoptosis alone (1-5), apoptosis and autophagy (22) or autophagy alone (6-8) to exert its inhibitory role in tumor cells. The results of the present study confirmed that PAB induced apoptosis in RD cells, which was consistent with the data reported in previous studies (1-5). In addition, in the present study, apoptosis was accompanied by autophagy, which was consistent with the results of a previous study in human breast cancer MCF-7 cells (22). Currently, the mechanism by which PAB induces apoptosis or autophagy in specific types of cells is unknown. It was speculated that in various types of cells, different apoptotic or autophagic factors may determine the cell fate following PAB treatment. Different apoptotic or autophagic factors will be investigated in future studies.

PAB has been reported to exert its antitumor effects via disrupting tubulin function (20). The ability of PAB to disrupt tubulin formation in RD cells was examined in the present study, and the results demonstrated that PAB treatment resulted in the aggregation of microtubule fibers, which was consistent with a previous study (20). Human rhabdomyosarcoma can spread locally, regionally or distantly, depending on the aggressiveness of the tumor cells (9). In the present study PAB treatment appeared to inhibit cell migration. In addition, PAB induced cell cycle arrest at the G2/M phase following 12-h treatment, whereas the expression levels of $\gamma-\mathrm{H} 2 \mathrm{AX}$ and cyclin B1 were upregulated at $24 \mathrm{~h}$ post-treatment compared 
with those in the control group. These results suggested that PAB induced $M$ phase arrest. Therefore, PAB exerted its antitumor effects through multiple mechanisms of action.

In conclusion, the results of the present study demonstrated that PAB exerted its antitumor roles by inducing apoptosis, autophagy and cell cycle arrest in human rhabdomyosarcoma RD cells. Therefore, PAB may be considered a potential treatment agent for human rhabdomyosarcoma.

\section{Acknowledgements}

Not applicable.

\section{Funding}

This work was supported by the National Natural Science Foundation of China (grant nos. 81871634 and 81301416), the Postdoctoral Science Foundation of China (grant nos. 2014M561302 and 2015T80299), the Norman Bethune Program of Jilin University (grant no. 2015202), the Jilin Provincial Science and Technology Department (grant nos. 20140204004YY, 20160414025GH and 20190304064YY) and the Department of Human Resources and Social Security of Jilin Province (grant no. 2016014).

\section{Availability of data and materials}

All data generated or analyzed during the study are included in this published article.

\section{Authors' contributions}

JY, CL and FW designed the experiments; BW, TW, YW, WH performed the experiments; JY, CL, FW, BW, TW, YW, WH, SZ, YS, JL and YL analyzed the data. All authors have read and approved the manuscript.

\section{Ethics approval and consent to participate}

Not applicable.

\section{Patient consent for publication}

Not applicable.

\section{Competing interests}

The authors declare that they have no competing interests.

\section{References}

1. Pan DJ, Li ZL, Hu CQ, Chen K, Chang JJ and Lee KH: The cytotoxic principles of Pseudolarix kaempferi: Pseudolaric acid-A and -B and related derivatives. Planta Med 56: 383-385, 1990.

2. Gong XF, Wang MW, Tashiro S, Onodera $S$ and Ikejima T: Pseudolaric acid B induces apoptosis through p53 and Bax/Bcl-2 pathways in human melanoma A375-S2 cells. Arch Pharm Res 28: 68-72, 2005

3. Gong $\mathrm{X}$, Wang $\mathrm{M}$, Tashiro S, Onodera $\mathrm{S}$ and Ikejima T: Involvement of JNK-initiated p53 accumulation and phosphorylation of p53 in pseudolaric acid B induced cell death. Exp Mol Med 38: 428-434, 2006.
4. Yu JH, Cui Q, Jiang YY, Yang W, Tashiro S, Onodera S and Ikejima T: Pseudolaric acid B induces apoptosis, senescence, and mitotic arrest in human breast cancer MCF-7. Acta Pharmacol Sin 28: 1975-1983, 2007.

5. Yu JH, Wang HJ, Li XR, Tashiro S, Onodera S and Ikejima T: Protein tyrosine kinase, JNK, and ERK involvement in pseudolaric acid B-induced apoptosis of human breast cancer MCF-7 cells. Acta Pharmacol Sin 29: 1069-1076, 2008.

6. Yu J, Li X, Tashiro S, Onodera S and Ikejima T: Bcl-2 family proteins were involved in pseudolaric acid B-induced autophagy in murine fibrosarcoma L929 cells. J Pharmacol Sci 107: 295-302, 2008.

7. Yu J, Ren P, Zhong T, Wang Y, Yan M, Xue B, Li R, Dai C, Liu C, Chen $\mathrm{G}$ and $\mathrm{Yu}$ XF: Pseudolaric acid $\mathrm{B}$ inhibits proliferation in SW579 human thyroid squamous cell carcinoma. Mol Med Rep 12: 7195-7202, 2015

8. Wang Y, Gao H, Wu T, Wang Z, Song F, Chen A, Zhang J, Zhang W, Zhang $\mathrm{H}$ and $\mathrm{Yu}$ J: Pseudolaric acid B induced autophagy, but not apoptosis, in MRC5 human fibroblast cells. Oncol Lett 15: 863-870, 2018.

9. Dziuba I,Kurzawa P,Dopierala M,Larque AB and JanuszkiewiczLewandowska D: Rhabdomyosarcoma in children-current pathologic and molecular classfication. PoI J Pathol 69: 20-32, 2018.

10. Li FF, Yi S, Wen L, He J, Yang LJ, Zhao J, Zhang BP, Cui GH and Chen Y: Oridonin induces NPM mutant protein translocation and apoptosis in NPM1c+ acute myeloid leukemia cells in vitro. Acta Pharmacol Sin 35: 806-813, 2014.

11. Qi M, Yao G, Fan S, Cheng W, Tashiro S, Onodera S and Ikejima T: Pseudolaric acid B induces mitotic catastrophe followed by apoptotic cell death in murine fibrosarcoma L929 cells. Eur J Pharmacol 683: 16-26, 2012.

12. Ahn JH, Lee YW, Ahn SK and Lee M: Oncogenic BRAF inhibitor UAI-201 induces cell cycle arrest and autophagy in BRAF mutant glioma cells. Life Sci 104: 38-46, 2014.

13. Wang R, Xiao X, Wang PY, Wang L, Guan Q, Du C and Wang XJ: Stimulation of autophagic activity in human glioma cells by anti-proliferative ardipusilloside I isolated from Ardisia pusilla. Life Sci 110: 15-22, 2014

14. Li Z, Yu J, Liu L, Wei Z, Ehrlich ES, Liu G, Li J, Liu X, Wang H, Yu XF and Zhang W: Coxsackievirus A16 infection induces neural cell and non-neural cell apoptosis in vitro. PLoS One 9: e111174, 2014.

15. Lee YJ, Won AJ, Lee J, Jung JH, Yoon S, Lee BM and Kim HS: Molecular mechanism of SAHA on regulation of autophagic cell death in tamoxifen-resistant MCF-7 breast cancer cells. Int J Med Sci 9: 881-893, 2012.

16. Lee YZ, Yang CW, Chang HY, Hsu HY, Chen IS, Chang HS, Lee CH, Lee JC, Kumar CR, Qiu YQ, et al: Discovery of selective inhibitors of Glutaminase-2, which inhibit mTORC1, activate autophagy and inhibit proliferation in cancer cells. Oncotarget 5: 6087-6101, 2014.

17. He H, Feng YS, Zang LH, Liu WW, Ding LQ, Chen LX, Kang N, Hayashi T, Tashiro S, Onodera S, et al: Nitric oxide induces apoptosis and autophagy; autophagy down-regulates NO synthesis in physalin A-treated A375-S2 human melanoma cells. Food Chem Toxicol 71: 128-135, 2014.

18. Han Y, Yang YN, Yuan HH, Zhang TT, Sui H, Wei XL, Liu L, Huang P, Zhang WJ and Bai YX: UCA1, a long non-coding RNA up-regulated in colorectal cancer influences cell proliferation, apoptosis and cell cycle distribution. Pathology 46: 396-401, 2014.

19. Lee H, Chin H, Kim K and Lee D: ERBB3 knockdown induces cell cycle arrest and activation of Bak and Bax-dependent apoptosis in colon cancer cells. Oncotarget 5: 5138-5152, 2014.

20. Wong VK, Chiu P, Chung SS, Chow LM, Zhao YZ, Yang BB and Ko BC: Pseudolaric acid B, a novel microtubule-destabilizing agent that circumvents multidrug resistance phenotype and exhibits antitumor activity in vivo. Clin Cancer Res 11: 6002-6011, 2005.

21. Song F, Yu X, Zhang H, Wang Z, Wang Y, Meng X and Yu J: Pseudolaric acid $\mathrm{B}$ inhibits neuroglioma cell proliferation through DNA damage response. Oncol Rep 38: 2211-2218, 2017.

22. Yu J, Chen C, Xu T, Yan M, Xue B, Wang Y, Liu C, Zhong T, Wang Z, Meng X, et al: Pseudolaric acid B activates autophagy in MCF-7 human breast cancer cells to prevent cell death. Oncol Lett 11: 1731-1737, 2016.

This work is licensed under a Creative Commons Attribution-NonCommercial-NoDerivatives 4.0 International (CC BY-NC-ND 4.0) License. 